\title{
Lack of a Regulatory Function for Glutamine Synthetase Protein in the Synthesis of Glutamate Dehydrogenase and Nitrite Reductase in Escherichia coli $\mathbf{K} 12$
}

\author{
By B. MARY NEWMAN* AND J. A. COLE \\ Department of Biochemistry, University of Birmingham, \\ P.O. Box 363, Birmingham BI5 $2 T T$ \\ (Received 30 June 1976; revised 27 August 1976)
}

\begin{abstract}
SUMMAR Y
Synthesis of glutamine synthetase (GS) in anaerobic batch cultures of Escherichia coli was repressed when excess $\mathrm{NH}_{4}{ }^{+}$was available, but derepressed during growth with a poor nitrogen source. In wild-type bacteria there was only a weak inverse correlation between the activities of GS and glutamate dehydrogenase (GDH) during growth in various media. No positive correlations were found between the activities of GS and nitrite reductase, or between GS and cytochrome $c_{552}$ : both of these proteins were synthesized normally by mutants that contained no active GS. Although activities of GS and GDH were low in two mutants that are unable to synthesize cytochrome $c_{552}$ or reduce nitrite because of defects in the nir $A$ gene, the nir $A$ defect was separated from the GS and GDH defects by transduction with bacteriophage PI. Attempts to show that catabolite repression of proline oxidase synthesis could be relieved during $\mathrm{NH}_{4}{ }^{+}$starvation also failed. It is, therefore, unlikely that nitrite reduction or proline oxidation by $E$. coli are under positive control by GS protein. The regulation of the synthesis of enzymes for the utilization of secondary nitrogen sources in $E$. coli is, therefore, different from that in Klebsiella aerogenes, but is similar to that in Salmonella typhimurium.
\end{abstract}

\section{INTRODUCTION}

We recently reported that continuous cultures of Escherichia coli strains OR75 and $\mathrm{Hfr}$ Cavalli can grow anaerobically with nitrite as the sole nitrogen source (Cole et al., 1974). Yields of bacteria were similar when growth was limited by the concentration of either nitrite or ammonium in the feed, and under both conditions synthesis of nitrite reductase, cytochrome $c_{552}$, glutamate dehydrogenase $(\mathrm{GDH})$ and glutamine synthetase (GS) were derepressed. The concomitant derepression or induction of GS and GDH in E. coli was unexpected because it was inconsistent with the proposed mechanism for regulation of GDH synthesis in the related bacterium, Klebsiella aerogenes (Brenchley, Prival \& Magasanik, I973). It was suggested that in the latter organism, GS is the repressor for GDH synthesis because the activity of GDH was inversely proportional to the activity of GS during growth in different media: furthermore, GS synthesis was regulated normally in mutants unable to synthesize GDH, but GDH synthesis was derepressed in mutants defective in GS (Brenchley et al., 1973). Although GS synthesis in $E$. coli appeared to be regulated by $\mathrm{NH}_{4}{ }^{+}$and by glutamine, as in $K$. aerogenes, we suggested that GDH synthesis might be regulated differently in the two organisms (Cole et al., 1974). 


\section{Table I. Origin of strains of E. coli}

\begin{tabular}{|c|c|c|}
\hline Strain & Phenotype or genotype $\dagger$ & Source or method of isolation \\
\hline Hfr Cavalli & Hfr met & NCIBI0237; NCIB, Torrey Research Station, Aberdeen \\
\hline OR56 & Prototrophic Hfr & R. Curtiss III \\
\hline OR75 & Prototrophic Hfr & R. Curtiss III \\
\hline OR75 Chl5 & $\mathrm{Chl}^{-} \mathrm{Gas}^{-} \mathrm{Nar}^{-}$ & 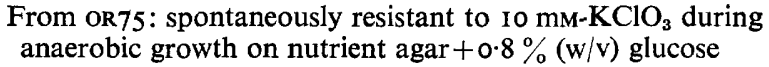 \\
\hline FS323 & $g \ln A$ his & B. A. Tyler \\
\hline${ }^{*} \mathrm{CB} 40$ & $\operatorname{nir} A I$ & See Cole \& Ward (1973) \\
\hline св64 & cysB $\operatorname{trp}$ & M. Jones-Mortimer \\
\hline $\mathrm{CB} 70$ & $g \ln A 67$ & S. B. Primrose \\
\hline CB7I & $g \ln A^{+} \mathrm{met}^{+}$ & $\begin{array}{l}\text { Conjugate CB70 } \times \text { Hfr Cavalli for } 60 \text { min at } 37^{\circ} \mathrm{C} \text {. Select for } \\
\text { Gln }{ }^{+} \text {; purify Gln } \text { Met }^{+} \text {recombinants }\end{array}$ \\
\hline $\mathrm{CB} 72$ & $g \ln A^{+}$ & $\begin{array}{l}\text { Transduce CB70 with bacteriophage PI propagated on oR75. } \\
\text { Then as for CB7I }\end{array}$ \\
\hline CB98 & nir $A$ I cys $B^{+}$pro trp his & $\begin{array}{l}\text { E. coli } \mathrm{F}^{-} \text {pro his trp cysB } \times \text { PI propagated on } \mathrm{CB} 40 \text {. Select } \\
\text { Cys }^{+} \text {transductants; purify } \mathrm{Cys}^{+} \text {Nir- clone }^{-}\end{array}$ \\
\hline${ }^{*} \mathrm{CB} 207$ & nir $A 2$ & $\begin{array}{l}\text { NTG mutagenesis of oR } 56 \text {. Select small colonies after anaero- } \\
\text { bic growth with } 5 \mathrm{~mm}-\mathrm{NO}_{2}^{-}+0 \cdot \mathrm{ImM}_{\mathrm{N}} \mathrm{NH}_{4}^{+} \text {as nitrogen } \\
\text { source. The nir defect was cotransducible with cys } B^{+}\end{array}$ \\
\hline CB222 & nirAI pro trp recA & $\begin{array}{l}\text { Conjugate CB98 with KLI6-99. Select for } \mathrm{His}^{+} \text {; purify } \mathrm{Rec}^{-} \\
\text {Nir }^{-} \text {clone }\end{array}$ \\
\hline CB240 & gln $A$ his Str $^{-}$ & $\begin{array}{l}\text { FS323 spontaneously resistant to } 100 \mu \mathrm{g} \text { streptomycin sulphate } \\
\mathrm{ml}^{-1}\end{array}$ \\
\hline $\mathrm{CB} 240 \mathrm{~F}^{\prime} g \ln A^{+}$ & $g \ln A \mathrm{Str}^{-} / g \ln A^{+}$ & Conjugate CB240 with JCI 553/KLFI33. Purify GIn ${ }^{+}$Str $^{-}$clone \\
\hline CB24I & $g \ln A$ his $^{+}$rec $A$ Str $^{-}$ & $\begin{array}{l}\text { Conjugate CB240 with KLI6-99. Select for } \mathrm{His}^{+} \text {; purify } \mathrm{Rec}^{-} \\
\text {GIn }^{-} \text {clone }\end{array}$ \\
\hline СВ24I $F^{\prime} g \ln A^{+}$ & $\operatorname{gln} A \operatorname{rec} A \operatorname{Str}^{-} / g \ln A^{+}$ & Conjugate CB24I with JCI 553/KLFI33. Purify $\mathrm{Gln}^{+} \mathrm{Str}^{-}$clone \\
\hline CB243 and CB244 & $\operatorname{nir} A I \operatorname{cys} B^{+} \operatorname{trp}$ & CB6 $4 \times$ PI propagated on CB40. Purify $\mathrm{Cys}^{+} \mathrm{Nir}^{-}$clones \\
\hline JCI $553 /$ KLFI33 & $g \ln A^{+} / g \ln A^{+} \operatorname{rec} A$ & B. Bachmann \\
\hline KLI 6-99 & Hfr recAI thi & M. Jones-Mortimer \\
\hline
\end{tabular}

* CB40 and CB207 carry at least one other mutation in a gene which regulates GS and GDH synthesis. $\uparrow$ The symbols nir and $\mathrm{Nir}^{-}$refer to the genotype and phenotype of mutants that are unable to reduce nitrite during anaerobic growth.

The growth conditions used by Magasanik and his colleagues differed from those of our earlier experiments, not only because $K$. aerogenes was grown aerobically instead of anaerobically, but also because bacteria were grown in batch rather than in continuous culture. We now report the results of experiments designed to show how GS and GDH synthesis in anaerobic batch cultures of $E$. coli are regulated by the composition of the growth medium, and whether GS regulates GDH synthesis in this organism.

In addition to its catalytic role and its postulated role as a repressor of GDH genes, unadenylylated GS protein activates transcription of Klebsiella genes that are involved in the metabolism of secondary nitrogen sources such as histidine and possibly elemental nitrogen (Tyler, Deleo \& Magasanik, 1974; Tubb, 1974; Streicher et al., 1974). Not only was there a strong correlation between the activities of GS and nitrite reductase during continuous culture experiments in which nitrite was the only nitrogen source for growth (Cole et al., 1974), but also.mutants have been isolated that appear to be defective in the regulation of both of these proteins (Kavanagh \& Cole, 1976). We have, therefore, investigated whether GS protein is required for nitrite reduction and cytochrome $c_{552}$ synthesis in E. coli. 


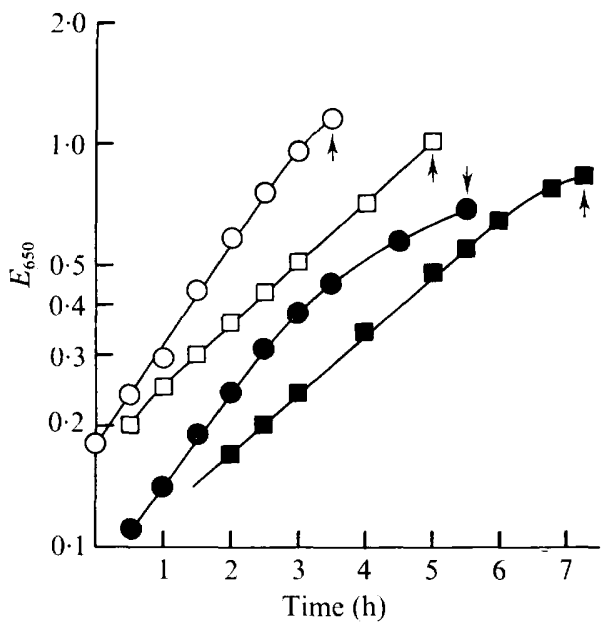

Fig. I. Growth rate of E. coli OR75 in nitrogen-free salts plus $0.8 \%(\mathrm{w} / \mathrm{v})$ glucose supplemented with: 0.1 g Casamino acids $\mathrm{l}^{-1}(\bullet) ; \mathrm{I} \cdot 0 \mathrm{~g}$ Casamino acids $\mathrm{l}^{-1}$ plus $20 \mathrm{mM}-\mathrm{NH}_{4} \mathrm{Cl}(\mathrm{O}) ; 20 \mathrm{mM}-$ $\mathrm{NH}_{4} \mathrm{Cl}(\square)$; or $5 \mathrm{~mm}-\mathrm{NaNO}_{2}(\mathbf{\square})$. Conical flasks (2 1 capacity) containing $\mathrm{I} \cdot 81$ medium equilibrated at $37^{\circ} \mathrm{C}$ were inoculated with $200 \mathrm{ml}$ of a stationary-phase culture of E. coli OR75 in similar medium. The arrows indicate the stages in the growth cycle at which bacteria were harvested for enzyme analyses.

\section{METHODS}

The origins of the various strains of Escherichia coli are presented in Table I. Nitrogenfree (NF) salts contained (per 1 distilled water): $10.5 \mathrm{~g} \mathrm{~K}_{2} \mathrm{HPO}_{4} ; 4.5 \mathrm{~g} \mathrm{KH}_{2} \mathrm{PO}_{4}$; I $\mathrm{g}$ trisodium citrate; $125 \mathrm{mg} \mathrm{Na}_{2} \mathrm{SO}_{4}$; and $5 \mathrm{ml}$ sulphur-free trace metals (Cole et al., 1974). The carbon and energy source was glucose at $27 \mathrm{mM}$, and nitrogen sources were as indicated in the text: these were added aseptically before inoculation from sterile stock solutions of $40 \%$ $(\mathrm{w} / \mathrm{v})$ glucose, $20 \%(\mathrm{w} / \mathrm{v})$ Casamino acids, $2 \mathrm{M}-\mathrm{NH}_{4} \mathrm{Cl}$ and $\mathrm{I} \mathrm{M}-\mathrm{NaNO}_{2}$. Inocula for batch cultures were aerated at $37^{\circ} \mathrm{C}$ for 6 to $8 \mathrm{~h}$ in $20 \mathrm{ml}$ Lennox (1955) broth, and were transferred to $200 \mathrm{ml}$ of prewarmed NF salts in a $250 \mathrm{ml}$ conical flask. After $\mathrm{I} 6 \mathrm{~h}$ at $37^{\circ} \mathrm{C}$ without aeration, the whole culture was transferred into I.81 NF salts in a 21 conical flask.

Bacteria were harvested and washed as described previously (Cole et al., 1974) and were resuspended in two to five times their volume of $50 \mathrm{~mm}$-Tris $/ \mathrm{HCl}$ plus $5 \mathrm{~mm}$-EDTA plus $5 \mathrm{~mm}$-ascorbate, $\mathrm{pH} 8 \cdot 0$. They were broken by passage through a French pressure cell at $4^{\circ} \mathrm{C}$ and $69 \mathrm{MPa}$ ( $10000 \mathrm{lbf} \mathrm{in}^{-2}$ ). Cell extracts were prepared and enzymes were assayed as described previously (Cole et al., 1974). Controls for glutamate synthase assays were performed as recommended by Brenchley (1973).

Lennox (I955) broth was used for conjugation experiments. Recipient and donor cultures in the exponential phase of growth were mixed in a ratio of between 5 and $20: 1$ with $10 \mathrm{ml}$ broth which had been warmed to $37^{\circ} \mathrm{C}$. After I min of vigorous aeration, mating was allowed to proceed with extremely gentle agitation. Transduction procedures were those of Lennox (1955) with only minor modifications.

\section{RESULTS}

Growth rates on different nitrogen sources

The mean generation time for Escherichia coli OR75 during the exponential phase of anaerobic growth was $\mathrm{I} \cdot 98 \mathrm{~h}$ with $20 \mathrm{mM}^{-\mathrm{NH}_{4}}{ }^{+}, \mathrm{I} \cdot 2 \mathrm{~h}$ with $20 \mathrm{mM}_{-} \mathrm{NH}_{4}{ }^{+}$and $\mathrm{I}$ g Casamino acids $\mathbf{l}^{-1}$, 
Table 2. Effect of $\mathrm{NH}_{\mathbf{4}}{ }^{+}$during growth on the synthesis of glutamine synthetase by batch cultures of E. coli

GS activities are expressed in $\mathbf{n m o l ~} \mathrm{min}^{-1}$ (mg protein) ${ }^{-1}$. Induction ratios for GS are expressed as the ratio of means of the GS activities of bacteria grown without and with $20 \mathrm{~mm}-\mathrm{NH}_{4}{ }^{+}$added to $\mathrm{I} \mathbf{g}$ Casamino acids $\mathbf{1}^{-1}$. The number of subunits adenylylated in the GS dodecamer (n) is calculated from the expression $12(\mathrm{I}-a \mid b)$, where $a$ is the activity of GS assayed with $60 \mathrm{mM}-\mathrm{Mg}^{2+}$ and $b$ is the activity without added $\mathbf{M g}^{2+}$. Results of two independent experiments with each nitrogen source are shown so that the reproducibility of the data can be assessed.

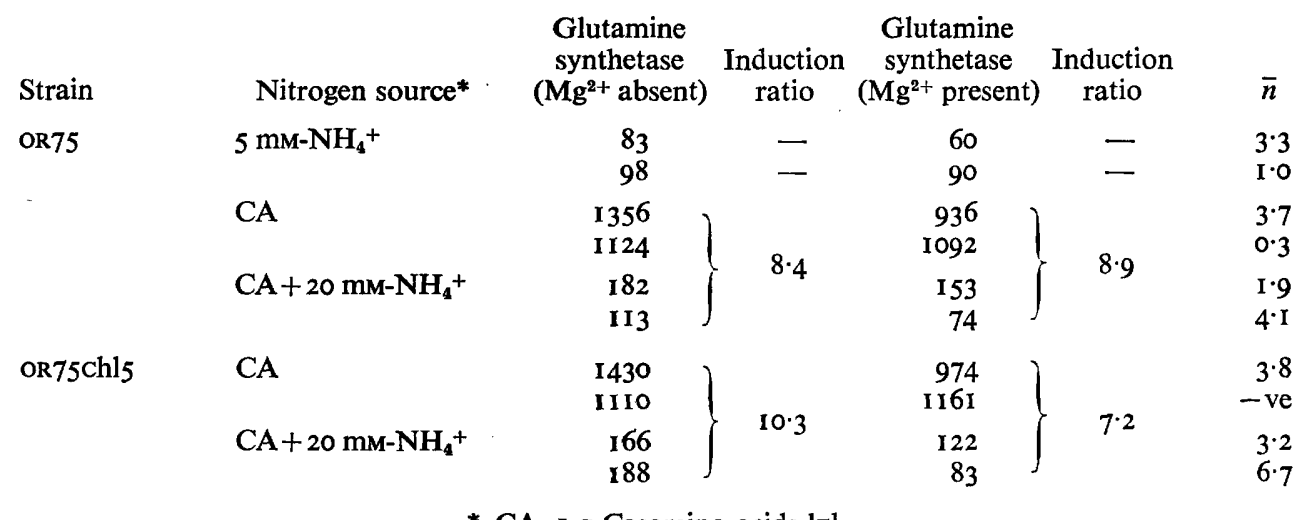

$\mathrm{I} \cdot 33 \mathrm{~h}$ with Casamino acids alone, and $2.08 \mathrm{~h}$ with $5 \mathrm{~mm}$-nitrite as the nitrogen source (Fig. I). When the nitrogen source was a limited supply of Casamino acids, the growth rate gradually declined at extinctions greater than 0.35 , which corresponds to a cell density of $150 \mathrm{mg}$ dry weight $\mathrm{1}^{-1}$. The arrows in Fig. I indicate the stages in the growth cycles at which bacteria were harvested for enzyme analyses: no nitrite remained in the culture supernatant when wild-type bacteria were grown with this nitrogen source.

\section{Effect of $\mathrm{NH}_{4}{ }^{+}$on glutamine synthetase}

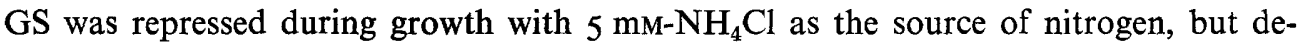
repressed during growth with I $g$ Casamino acids $1^{-1}$ (compare lines I to 4 , Table 2). When Casamino acids were supplemented with an excess of $\mathrm{NH}_{4} \mathrm{Cl}$, GS synthesis was again repressed (Table 2, lines 5 and 6). In each of these experiments the activity of GS was only slightly inhibited by $60 \mathrm{mM}-\mathrm{Mg}^{2+}$; the enzyme was, therefore, predominantly unadenylylated. Essentially similar data were obtained from experiments with $E$. coli strain $\mathrm{CB}_{4}$ (data not shown) and with a spontaneous mutant of strain OR75 which is resistant to 10 mM$\mathrm{KClO}_{3}$ during anaerobic growth (Table 2, lines 7 to I0).

\section{Effect of $\mathrm{NH}_{4}^{+}$on glutamate dehydrogenase, glutamate synthase, nitrite reductase and cytochrome $c_{552}$ synthesis}

The activities of GDH and glutamate synthase were higher when strains oR75 and OR75 Chl5 were grown with excess $\mathrm{NH}_{4}{ }^{+}$than during growth with Casamino acids alone, but the GDH activities were not inversely proportional to those of GS (Tables 2 and 3 ). During growth with excess $\mathrm{NH}_{4}^{+}$, GS was repressed 7- to Io-fold relative to the activity during growth with Casamino acids alone, but GDH activity was only derepressed by a factor of $I \cdot 7$ to $2 \cdot 8$. Similar induction ratios can be calculated for glutamate synthase (see 
Table 3. Effect of $\mathrm{NH}_{4}+$ during growth on the activities of glutamate dehydrogenase and glutamate synthase

Enzyme activities are expressed in $\mathrm{nmol} \mathrm{min}^{-1}\left(\mathrm{mg}\right.$ protein) ${ }^{-1}$. Induction ratios are the inverse of those in Table 2, that is, the ratio of the means of the enzyme activities in bacteria grown with and without $20 \mathrm{mM}-\mathrm{NH}_{4}{ }^{+}$added to the Casamino acids. Results of two independent experiments with each nitrogen source are shown so that the reproducibility of the data can be assessed.

\begin{tabular}{|c|c|c|c|c|c|}
\hline Strain & Nitrogen source* & $\begin{array}{c}\text { Glutamate } \\
\text { dehydrogenase }\end{array}$ & $\begin{array}{l}\text { Induction } \\
\text { ratio }\end{array}$ & $\begin{array}{c}\text { Glutamate } \\
\text { synthase }\end{array}$ & $\begin{array}{l}\text { Induction } \\
\text { ratio }\end{array}$ \\
\hline \multirow[t]{2}{*}{ OR75 } & $\mathrm{CA}$ & $\begin{array}{l}168 \\
144\end{array}$ & \multirow[b]{2}{*}{$1 \cdot 7$} & $\begin{array}{r}\text { I26 } \\
8 \mathrm{I}\end{array}$ & \multirow{2}{*}{$\mathrm{I} \cdot 8$} \\
\hline & $\mathrm{CA}+20 \mathrm{mM}^{-\mathrm{NH}_{4}}{ }^{+}$ & $\begin{array}{l}279 \\
237\end{array}$ & & $\begin{array}{l}203 \\
171\end{array}$ & \\
\hline \multirow[t]{2}{*}{ OR75 Chl5 } & CA & $\begin{array}{l}181 \\
183\end{array}$ & \multirow{2}{*}{2.8} & $\begin{array}{r}14 I \\
89\end{array}$ & \multirow{2}{*}{$2 \cdot 5$} \\
\hline & $\mathrm{CA}+20 \mathrm{mM}^{-\mathrm{NH}_{4}}{ }^{+}$ & $\begin{array}{l}630 \\
378\end{array}$ & & $\begin{array}{l}279 \\
292\end{array}$ & \\
\hline
\end{tabular}

Table 4. Effect of the nitrogen source during growth on cytochrome $c_{552}$ synthesis and nitrite reductase activity

Enzyme activities are expressed in nmol $\min ^{-1}(\mathrm{mg} \text { protein })^{-1}$; cytochrome $c_{552}$ synthesis in pmol (mg protein $)^{-1}$. Each line of data is the average of at least two experiments.

\begin{tabular}{|c|c|c|c|c|}
\hline Strain & Nitrogen source* & $\begin{array}{c}\text { Glutamine } \\
\text { synthetase } \\
\left(\mathbf{M g}^{2+} \text { absent) }\right.\end{array}$ & $\begin{array}{c}\text { Nitrite } \\
\text { reductase }\end{array}$ & Cytochrome $c_{552}$ \\
\hline OR75 & $\begin{array}{l}\mathrm{CA} \\
\mathrm{CA}+20 \mathrm{mM}^{-\mathrm{NH}_{4}}{ }^{+} \\
20 \mathrm{mM}^{-\mathrm{NH}_{4}^{+}} \\
5 \mathrm{mM}^{+} \mathrm{NO}_{2}^{-} \\
20 \mathrm{mM}^{-} \mathrm{NH}_{4}+5 \mathrm{mM}^{+} \mathrm{NO}_{2}^{-}\end{array}$ & $\begin{array}{r}1092 \\
148 \\
171 \\
424 \\
91\end{array}$ & $\begin{array}{r}63 \\
89 \\
78 \\
510 \\
437\end{array}$ & $\begin{array}{c}<20 \text { to } 40 \\
50 \\
32 \\
286 \\
242\end{array}$ \\
\hline OR $75 \mathrm{Chl}^{5}$ & $\begin{array}{l}\mathrm{CA} \\
\mathrm{CA}+20 \mathrm{~mm}-\mathrm{NH}_{4}+\end{array}$ & $\begin{array}{r}1270 \\
177\end{array}$ & $\begin{array}{l}575 \\
629\end{array}$ & $\begin{array}{l}165 \\
265\end{array}$ \\
\hline
\end{tabular}

Tables 2 and 3). The activity of GDH during growth with Casamino acids plus $20 \mathrm{~mm}$ $\mathrm{NH}_{4}{ }^{+}$was far lower $(<20 \%)$ than that observed when the same strain was grown either with $5 \mathrm{~mm}$-nitrite, or with $5 \mathrm{mM}$-nitrite plus $20 \mathrm{~mm}-\mathrm{NH}_{4}{ }^{+}$(Kavanagh \& Cole, 1976).

Nitrite reductase activity and cytochrome $c_{552}$ synthesis were partially derepressed or induced during anaerobic growth with $\mathrm{I} g$ Casamino acids $\mathbf{1}^{-1}$ as the nitrogen source, and specific activities or concentrations of these proteins did not decrease when excess $\mathrm{NH}_{4}{ }^{+}$ was added (Table 4 , lines $I$ and 2). The highest activities or concentrations of both of these proteins were found in bacteria which had been grown with $5 \mathrm{~mm}$-nitrite as the sole nitrogen

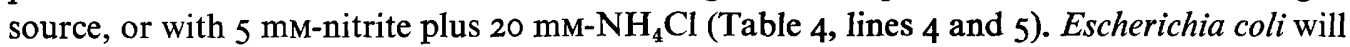
only tolerate low concentrations of nitrite, so it was impossible to grow bacteria with a large excess of this nitrogen source. The increased activity of GS in cultures grown with $5 \mathrm{mM}$ nitrite was not unexpected because bacteria were harvested after the last traces of nitrite had been metabolized: their growth-yield was therefore nitrogen-limiting. However, in contrast 
Table 5. Nitrite reduction and ammonia assimilation in mutants defective in nitrite reductase and glutamine synthetase

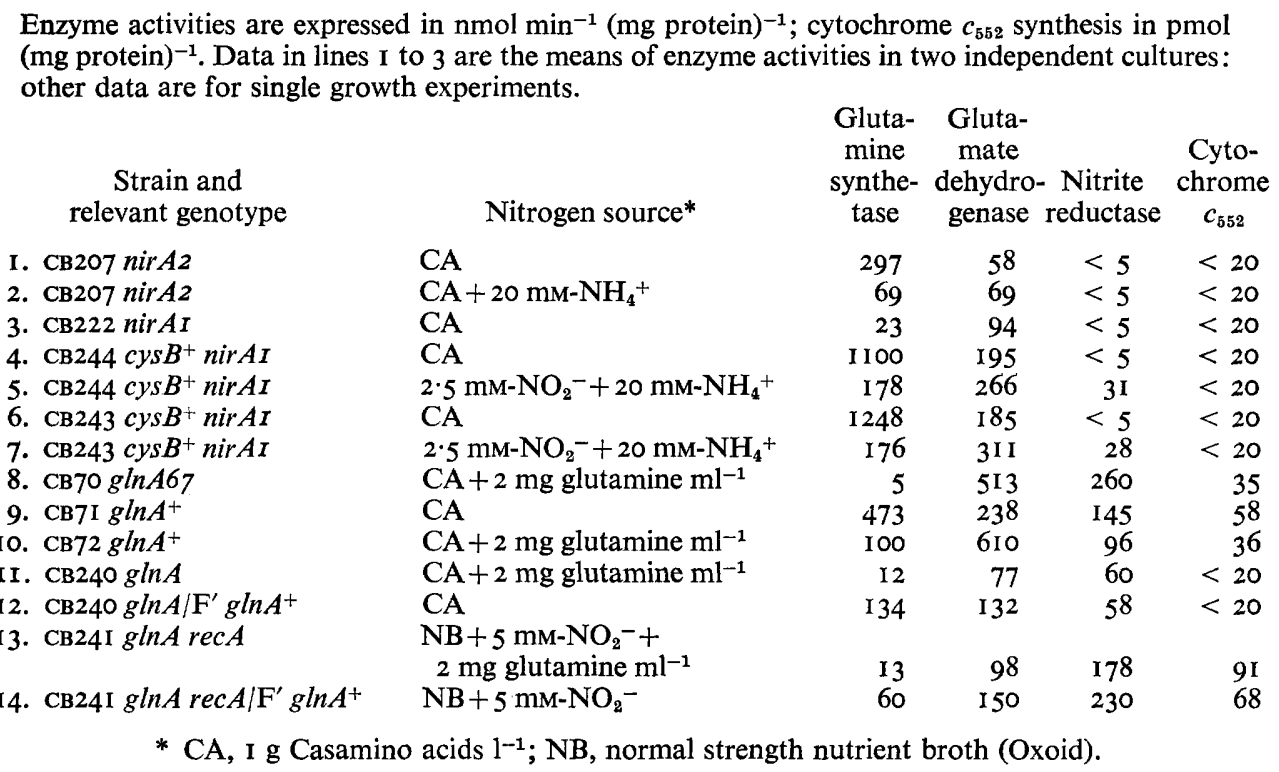

to the data from the earlier continuous culture experiments (Cole et al., I974), there were no correlations between the activities of GS and nitrite reductase, or between GS and the concentration of cytochrome $c_{552}$. Subsequent experiments were therefore designed to investigate whether GS protein is required for nitrite reduction to occur in these bacteria.

\section{Effects of mutations in genes for glutamine synthetase and nitrite reductase}

Mutants unable to reduce nitrite due to defects in the nir $A$ gene were isolated from two strains of $E$. coli: $\mathrm{CB} 222$ is a derivative of $\mathrm{CB} 40$, the original nir $A I$ mutant described by Cole \& Ward (I973); CB207 was selected for further study from a group of new isolates with the NirA- phenotype (Newman \& Cole, unpublished). Both CB207 and CB222 lacked nitrite reductase activity and cytochrome $c_{552}$, and GS and GDH were at least partially repressed irrespective of whether the supply of $\mathrm{NH}_{4}{ }^{+}$was limited or in excess (Table 5, lines I to 3 ). We were unable to demonstrate whether GS synthesis was regulated normally by $\mathrm{NH}_{4}{ }^{+}$in $\mathrm{CB} 40$ because no growth occurred when this strain was transferred to media used to demonstrate derepression of GS in wild-type bacteria. The nirAI defect carried by strain CB222 was transduced by bacteriophage $\mathrm{PI}_{\mathrm{I}}$ from $\mathrm{CB}_{4} 0$ into $\mathrm{CB}_{4} 4$ by selecting Cys ${ }^{+}$transductants that were unable to reduce nitrite. In four out of four of these transductants, synthesis of GS and GDH were regulated normally by $\mathrm{NH}_{4}{ }^{+}$, but cytochrome $c_{552}$ and nitrite reductase were absent: typical data are shown in lines 4 to 7 of Table 5. Six other $p y r F^{+}$nir $A$ or $c y s B^{+}$nir $A$ transductants constructed with phage which had been propagated on three different nir $A$ mutants grew normally in nitrogen-limited media. The original nir $A$ isolates, therefore, carry multiple mutations, one in the nir $A$ gene and at least one other that affects the rates of GS and GDH synthesis and growth in nitrogen-limited media. However, the loss of nitrite reductase activity and cytochrome $c_{552}$ synthesis was due to the defective nir $A$ gene rather than to the defective synthesis of GS protein. 
GS was virtually absent from $E$. coli $\mathrm{CB} 70$ which carries the $g \ln A 67$ defect in the structural gene for GS (Berberich, 1972). Nitrite reductase and GDH were more active in this strain than in OR75, and cytochrome $c_{552}$ was also detected (Table 5, line 8). The $g \ln A^{+}$allele from $E$. coli $\mathrm{Hfr}$ Cavalli was introduced into strain $\mathrm{CB} 70$ by conjugation, and recombinants that were both $\mathrm{Gln}^{+}$and $\mathrm{Met}^{+}$were purified by repeated single colony isolations on nutrient agar. Activities of nitrite reductase and GDH in these strains were lower than in CB70, but synthesis of GS had been restored: data for one of these strains, CB7I, are shown in line 9 of Table 5. Similar data were obtained with strain CB72, a derivative of CB70 in which the $g \ln A^{+}$allele from OR75 had been introduced by transduction with bacteriophage PI (Table 5, line I0). Two other strains CB240 and СB24I were constructed which carried the $g \ln A$ defect of $E$. coli strain $\mathrm{FS}_{323}$. CB24I was a $\mathrm{His}^{+} \mathrm{RecA}^{-}$derivative of $\mathrm{CB} 240$ which grew very poorly in minimal media: nutrient broth plus $5 \mathrm{~mm}$-nitrite was therefore used to obtain sufficient bacteria in which nitrite reductase and cytochrome $c_{552}$ synthesis had been induced. Nitrite reductase activity was detected in both of these mutants, and although GS was virtually absent, GDH activity was also low (Table 5, lines I I and I3). When the episome KLFI 33 which carried a $g \ln A^{+}$allele was transferred into these strains, GS activity was partially restored and the activity of GDH also increased: however, nitrite reductase activity and cytochrome $c_{552}$ synthesis were unaffected (Table 5, lines I 2 and I4).

\section{Growth with proline as the nitrogen source}

Histidine can be used either as a carbon source or as a nitrogen source for the growth of Klebsiella aerogenes. In the absence of a carbon source that can be metabolized more readily than histidine, cyclic adenosine $3^{\prime}: 5^{\prime}$-monophosphate (cyclic AMP) and the cyclic AMPbinding protein activate transcription of hut genes which specify the enzymes for histidine catabolism. These genes are also activated by unadenylylated GS when histidine is the only available nitrogen source (Tyler et al., 1974). Thus, catabolite repression of the hut operon is effectively reversed by $\mathrm{NH}_{4}{ }^{+}$-starvation, and $\mathrm{NH}_{4}{ }^{+}$-repression due to the lack of unadenylylated GS is reversed by depriving these bacteria of alternative carbon sources. Proline metabolism by $K$. aerogenes is believed to be subject to similar dual controls (Prival, Brenchley \& Magasanik, 1973), and, unlike histidine, proline is able to supply either carbon or nitrogen to support the growth of $E$. coli. If GS activates transcription of the genes for proline oxidase in $E$. coli, then wild-type bacteria should grow equally well with proline as the sole nitrogen source with a strong catabolite repressor (Epstein, Rothman-Denes \& Hesse, 1975). Escherichia coli OR75 was, therefore, plated on to solid media in which either

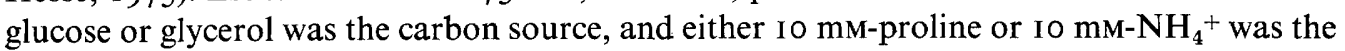
nitrogen source. After $48 \mathrm{~h}$ at $37^{\circ} \mathrm{C}$, very little growth had occurred on any of the proline plates, but large translucent colonies had formed on either type of $\mathrm{NH}_{4}^{+}$plate. After 72 to $96 \mathrm{~h}$ a mixture of normal and mucoid colonies had formed on the proline plus glycerol plates, but little growth had occurred on proline plus glucose. Bacteria from both the mucoid and the translucent colonies produced both types of clone when subcultured on to similar media, and growth on proline plus glycerol was always more rapid than growth on proline plus glucose. It appeared, therefore, that proline catabolism in $E$. coli was subject to strong catabolite repression by glucose even when $\mathrm{NH}_{4}{ }^{+}$was absent and when GS was presumably derepressed. 


\section{DISCUSSION}

Synthesis of GS in E. coli OR75 was repressed whenever $\mathrm{NH}_{4}{ }^{+}$was in excess and was apparently induced when batch cultures were supplied with a poor nitrogen source. These data are consistent with those from the earlier continuous culture experiments (Cole et al., I974), and confirm that GS synthesis is regulated by $\mathrm{NH}_{4}{ }^{+}$in this organism as in Klebsiella aerogenes (Brenchley et al., 1973), Salmonella typhimurium (Brenchley, Baker \& Patil, 1975; Betteridge \& Ayling, 1976) and Klebsiella pneumoniae (Tubb, 1974).

A recently isolated nirA mutant, $\mathrm{CB} 207$, which lacked nitrite reductase activity and cytochrome $c_{552}$ also had low activities of GS and GDH. Strains CB98 and its derivative, CB222, were constructed from the original nir $A$ mutant by cotransducing the nirAI defect with $c y s B^{+}$into a multiple auxotroph: GS and GDH were also apparently repressed in both of these strains (Table 5, and unpublished). Although this suggested that either the nir $A$ gene alone or the nir $A$ gene and other closely-linked genes regulated the synthesis of all four proteins, GS and GDH were regulated normally when another recipient, св64, was used to

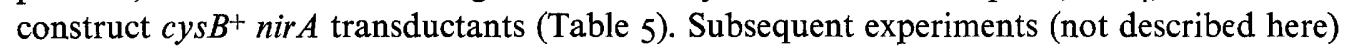
have confirmed that the GS and GDH defects of CB4O and CB207 are not closely linked to the nir $A$ defect. We therefore conclude that the recipient used to construct CB98 and СB222 must also carry defects in the regulation of GS and GDH. In subsequent experiments, no correlations were found between the cellular concentrations of GS and cytochrome $c_{552}$, or between GS and nitrite reductase activity. Nitrite reductase and cytochrome $c_{552}$ synthesis were induced by nitrite but they were not repressed by $\mathrm{NH}_{4}^{+}$(Table 4 ). Although these results are apparently in conflict with earlier data from continuous culture experiments, they are fully supported by studies with mutants defective in GS synthesis: these reduced nitrite normally (Table 5). Furthermore, OR75Chl5, which was resistant to chlorate because of a defect in an unidentified nitrate reductase gene, contained high activities or concentrations of nitrite reductase or cytechrome $c_{552}$ during anaerobic growth without nitrite (Table 4 ; for the original description of this phenotype, see Venables, Wimpenny \& Cole, I968). This partial constitutivity for nitrite reductase was not due to the constitutive synthesis of GS, however, because GS in this strain was regulated normally by $\mathrm{NH}_{4}{ }^{+}$(Table 2 ). It is, therefore, unlikely that nitrite reduction and nitrite assimilation by $E$. coli are under positive control by GS protein. Similarly, catabolite repression of proline oxidation by glucose was still apparent when proline was the only nitrogen source for growth. We were, therefore, unable to show that proline oxidase is regulated positively by GS as is histidase synthesis in $K$. aerogenes.

Although GS appears to be the repressor for GDH synthesis in $K$. aerogenes, other factors appear to be at least as important in regulating the activity of GDH in $E$. coli. We have previously suggested that GDH synthesis is stimulated by high intracellular concentrations of 2-oxoglutarate but inhibited by high concentrations of glutamate (Cole et al., 1974). Senior (1975) subsequently demonstrated that there was a direct correlation during growth in continuous culture between the activity of GDH and the 2-oxoglutarate: glutamine ratio. We have also demonstrated that GDH synthesis is apparently induced during anaerobic growth in minimal medium with nitrite, but repressed when Casamino acids or nutrient broth is added to growth media (Kavanagh \& Cole, 1976, and unpublished). Presumably Casamino acids and nutrient broth contain one or more corepressors of GDH synthesis, and these could include glutamate and glutamine. One cannot exclude the possibility that GS also repressed GDH synthesis, and data in Table 3 are consistent with this suggestion. It is apparent, however, that if such a regulatory mechanism is operative, it is weak compared 
with other controlling factors. Similar conclusions were recently drawn concerning GDH synthesis in Salmonella typhimurium (Brenchley et al., 1975).

In conclusion, we have been unable to demonstrate that GS is as important a factor in regulating nitrogen metabolism in $E$. coli as it is in $K$. aerogenes. This is possibly due to differences in the regulatory genes for GDH and proline oxidase in the two organisms rather than to differences in their GS proteins because genes for nitrogen fixation are expressed normally when the $g \ln A^{+}$gene from $E$. coli is introduced into a $g \ln A$ strain of $K$. aerogenes (Shanmugam \& Valentine, 1975).

We thank B. Bachmann, R. Curtiss III, M. Jones-Mortimer, S. B. Primrose and B. A. Tyler for bacterial strains; B. E. Compton for technical assistance; J. Guest, C. MacGregor, S. B. Primrose and S. C. Rittenberg for their helpful comments and criticisms; and the Science Research Council for supporting B.M.N. with a Research Studentship.

\section{REFERENCES}

Berberich, M. A. (1972). A glutamate-dependent phenotype in E. coli KI2: the result of two mutations. Biochemical and Biophysical Research Communications 47, I498-I503.

Betteridge, P. R. \& Ayling, P. D. (1976). The regulation of glutamine transport in wild-type and mutant strains of Salmonella typhimurium. Heredity 36, 29I-292.

BRENCHLEY, J. E. (I973). Effects of methionine sulfoximine and methionine sulfone on glutamate synthesis in Klebsiella aerogenes. Journal of Bacteriology 114, 666-673.

Brenchley, J. E., Prival, M. J. \& Magasanik, B. (I973). Regulation of the synthesis of enzymes responsible for glutamate formation in Klebsiella aerogenes. Journal of Biological Chemistry 248, 6I 22-6I 28.

Brenchley, J. E., BAKer, C. A. \& PATIL, L. G. (1975). Regulation of the ammonia assimilatory enzymes in Salmonella typhimurium. Journal of Bacteriology 124, I 82-189.

COLE, J. A. \& WARD, F. B. (1973). Nitrite reductase-deficient mutants of Escherichia coli K12. Journal of General Microbiology 76, $21-29$.

Cole, J. A., Coleman, K. J., Compton, B. E., Kavanagh, B. M. \& Keevil, C. W. (i974). Nitrite and ammonia assimilation by anaerobic continuous cultures of Escherichia coli. Journal of General Microbiology 85 , I I-22.

Epstein, W., Rothman-Denes, L. B. \& Hesse, J. (1975). Adenosine $3^{\prime}$ : 5'-cyclic monophosphate as mediator of catabolite repression in Escherichia coli. Proceedings of the National Academy of Sciences of the United States of America 72, 2300-2304.

Kavanagh, B. M. \& Cole, J. A. (1976). The regulation of nitrogen metabolism in batch and continuous cultures of Escherichia coli: facts and artefacts. In Continuous Culture: Applications and New Fields, Proceedings of the 6th International Symposium on Continuous Culture of Micro-organisms. Edited by A. C. R. Dean, D. C. Ellwood, C. G. J. Evans and J. Melling. Chichester: Ellis Horwood (in the Press).

LENNOX, E. S. (I955). Transduction of linked genetic characters of the host by bacteriophage PI. Virology I, I $90-206$.

Prival, M. J., Brenchley, J. E. \& Magasanik, B. (I973). Glutamine synthetase and the regulation of histidase formation in Klebsiella aerogenes. Journal of Biological Chemistry 248, 4334-4343.

SENIOR, P. J. (1975). Regulation of nitrogen metabolism in Escherichia coli and Klebsiella aerogenes: studies with the continuous culture technique. Journal of Bacteriology 123, 407-418.

Shanmugan, K. T. \& Valentine, R. C. (I975). Molecular biology of nitrogen fixation. Science 187, 919-924.

Streicher, S. L., Shanmugam, K. T., Ausubel, F., Morandi, C. \& Goldberg, R. B. (I974). Regulation of nitrogen fixation in Klebsiella pneumoniae: evidence for a role of glutamine synthetase as a regulator of nitrogenase synthesis. Journal of Bacteriology I20, 8I 5-82I.

TuBb, R. S. (1974). Glutamine synthetase and ammonium regulation of nitrogenase synthesis in Klebsiella. Nature, London 25r, 48I-485.

Tyler, B., Deleo, A. B. \& Magasanik, B. (1974). Activation of transcription of hut DNA by glutamine synthetase. Proceedings of the National Academy of Sciences of the United States of America 71, 225-229.

Venables, W. A., Wimpenny, J. W. T. \& Cole, J. A. (1968). Enzymic properties of a mutant of Escherichia coli $\mathrm{KI} 2$ lacking nitrate reductase. Archiv für Mikrobiologie 63, I I7-I 2 I. 